\title{
Critical Thinking Skills And Student Enthusiasm In Virtual-Based Learning For Thermodynamics Course
}

\author{
Fenno Farcis ${ }^{1}$, Enny Wijayanti, Gunarjo S. Budi, Pri Ariadi Cahya Dinata ${ }^{1}$ \\ ${ }^{l}$ Pendidikan Fisika, Fakultas Keguruan dan Ilmu Pendidikan, Universitas \\ Palangka Raya, Indonesia \\ ${ }^{1}$ Correspondence Address: Program Studi Pendidikan Fisika, FKIP, UPR \\ Gedung M-FKIP Jl. Yos Sudarso Palangka Raya \\ E-mail: fenno.farcis@ fkip.upr.ac.id
}

Receipt: Oct, 26, 2021; Revised: Nov, 05, 2021; Accepted: Nov, 10, 2021

\begin{abstract}
This study aims to determine the critical thinking skills and enthusiasm of prospective physics educator students in learning virtual-based thermodynamics courses. This type of research is a survey research that begins with the development of research instruments using a 4-D development model according to Thiagarajan consisting of 4 stages, namely: define, design, develop, and disseminate. The research subjects were 20 students of the physics education study program at the University of Palangka Raya in the Thermodynamics class. Collecting data using validation methods, evaluation techniques and student enthusiasm questionnaires. Quantitative data were obtained from the results of critical thinking skills assessment and student enthusiasm questionnaires in the virtual-based thermodynamics learning process given at the end of the lesson. The data analysis technique used quantitative and qualitative descriptive inferential statistical test analysis. The results obtained are the test instrument for critical thinking skills learning outcomes and student enthusiasm questionnaire instruments in virtual-based thermodynamic learning that have been developed are included in the valid criteria, with Cronbach's Alpha reliability $(\square) 0.712$ $<0.899$ which is included in the high reliability criteria; 1) students' critical thinking skills are $87 \%$ with an average $\mathrm{N}$-gain of 0.86 critical thinking skills which is in the high criteria; 2) student enthusiasm on average $91.7 \%$ students feel enthusiastic about thermodynamics learning that is carried out virtually, which can be seen from the aspect of student's intention to take part in learning by $95 \%$, aspect of goal $90 \%$, aspect of self-potential by $90 \%$ and positive thinking aspect by $91.7 \%$.
\end{abstract}

Keywords: Critical thinking skills, enthusiasm, thermodynamics, virtual based learning.

\section{INTRODUCTION}

Physics is one of the basic sciences (basic science) which is the foundation in individual thinking patterns to be developed to become the main supporter in problem solving, especially with the application of practical science (Sunaryo, 2011). Physics studies natural phenomena involving matter, energy, and their interactions through observation, experimentation, and analysis. The essence of physics is physics as a product, attitude, and process. Physics as a product is a collection of knowledge that can be in the form of facts, concepts and principles. 
One part of science that is closely related to the practical application of physics and technology to various aspects of everyday life is thermodynamics.

Thermodynamics is closely related to the universe and has an important role in human life. Hassan \& Mat (2005) suggested that thermodynamics is a basic knowledge related to energy and has long been an important part of the engineering curriculum. Thermodynamics is a subject related to energy and is one of the materials needed to understand natural phenomena. Thermodynamics is an important topic that must be studied in physics because it has many applications in science and technology (Kulkarni \& Tambade, 2013). Thermodynamics learning content is fully contained in the curriculum.

The curriculum of the Physics Education Study Program at the University of Palangka Raya places the thermodynamics course as one of the expertise courses. This course aims to strengthen students' understanding of basic physics and equip students to take advanced courses. The thermodynamics course is one of the courses that contains physics concepts that must be mastered by physics education students. The concept of thermodynamics is closely related to events in everyday life. Understanding the concept of thermodynamics is needed by students to explain physical phenomena in everyday life. The results of the research by Tatar \& Oktay (2011) suggest that students who do not understand the concept of physics can certainly not explain everyday phenomena using physics concepts. Students have not been able to connect a concept with other concepts because each of these concepts has not been fully constructed in their thinking abilities.

Students' thinking ability to master physics concepts requires basic thinking skills (Novak \& Gowin, 1985), as well as complex (high-level) thinking skills, including critical thinking skills (Costa \& Pressceincen, 1985). Critical thinking is one of the higher order thinking skills or HOTS in addition to creative thinking (creative thinking), problem solving (creative thinking), problem solving (problem solving), and reflective thinking (reflective thinking). There are several definitions of critical thinking put forward by experts, including Paul \& Elder (2002) stating that critical thinking is a popular term in the fields of education, psychology, philosophy, and has been defined and theoretically as a "set of intellectual standards" that can be used. by an individual in thought. The definition of critical thinking according to Halpern (2003) is thinking that is purposeful, reasoned and goal-directed - the kind of thinking needed in solving problems, formulating inferences, calculating tendencies, and making decisions. Moore (2005) defines critical thinking as the ability to critically analyze complex situations. The rapidly changing world, increasing complexity, and increasing interdependence make critical thinking a prerequisite for social and economic sustainability. The learning process that does not train students' critical thinking skills tends to form students who are passive and less able to optimize their thinking skills by only accepting what is delivered by the lecturer. 
Efforts to improve critical thinking skills need to be done by paying attention to the phases of critical thinking skills. Ennis (2001) divides three phases of critical thinking in the elementary clarification group, namely (1) identifying or formulating questions, (2) analyzing arguments, and (3) asking and answering clarifying questions and or challenging questions.

Covid-19 (Corona virus Disease 2019) is an infectious disease that causes mild disorders of the respiratory system, severe lung infections, and can cause death. Indonesia is one of the countries affected by COVID-19. The steps taken by the Indonesian government to break the chain of spread of COVID-19 are to carry out Social Distancing and Physical Distancing, limit social interaction with other people, and reduce activities outside the home. The sector that is also affected by the emergence of the COVID-19 outbreak is the sector. Learning activities that were initially carried out face-to-face were then transferred to independent learning activities at home by students and required educators and students to carry out virtual learning activities. Virtual learning is defined as the delivery of learning through electronic media that bridges the gap caused when educators and students are separated both in time and place (adapted from Leonard, 1996; Fell, 1996).

The thermodynamics course as one of the courses in the Physics Education Study Program at the University of Palangka Raya is also carried out on a virtual basis. Learning with internet media is still relatively new for educators (lecturers) and students (students), but it is still carried out with the aim of producing prospective physics educators who have high-level thinking skills, one of which is critical thinking skills. Lecturers are expected to be able to implement various approaches, models, and methods in learning to make students able to understand the abstract and macroscopic concepts of thermodynamics that are difficult to describe in real terms without ignoring the need for learning that tends to use a mathematical approach in teaching thermodynamic concepts. Students are expected to be actively and enthusiastically involved in the process of constructing thermodynamic concepts because understanding difficult and abstract concepts can be done where students are involved in the process of constructing a concept in their mind and science skills through the scientific process (Risamasu, 2016). Student enthusiasm in the learning process affects student learning achievement. Humans need enthusiasm and enthusiasm not only so that they can continue to work, but will also make them do their jobs with joy. And when the problems and challenges of life get bigger, then in the end, all that will be left are people with high enthusiasm. Because they are the ones who are able to endure all the difficulties and problems of life (Andriewongso, 2009). The signs of someone who has enthusiasm, namely the presence of trust, awareness, having a source of strength, positive attitude, and self-confidence (Muhajid, 2012).

The thoughts of various experts, facts in the field, as well as various relevant research results that have been described above are the rationale for the need to 
conduct a study that aims to determine the critical thinking skills and enthusiasm of the students of the Physics Education Study Program at the University of Palangka Raya in the thermodynamics course carried out virtual based. The results of the study are expected to be an evaluation material for the implementation of thermodynamics learning as well as other courses which are also implemented on a virtual basis.

The problems that have been stated in the background of the problem are the basis of the research objectives as follows:

1. to describe critical thinking skills of students of the Physics Education Study Program at the University of Palangka Raya in the thermodynamics course which is carried out on a virtual basis.

2. to describe the enthusiasm of the students of the Physics Education Study Program at the University of Palangka Raya in the thermodynamics course which is carried out on a virtual basis.

\section{METHOD}

This research is a survey research which was preceded by development research which aims to produce a design of critical thinking skills evaluation instrument and student enthusiasm questionnaire instrument for virtual-based thermodynamics learning. The development of critical thinking skills evaluation instruments and student enthusiasm questionnaire instruments for virtual-based thermodynamics learning refers to the development model of Sivasailam Thiagarajan, Dorothy S. Semmel, and Melvyn I. Semmel (1974) (Trianto, 2009). The 4-D development model according to Thiagarajan consists of 4 stages: define (definition), design (design), develop (development), and disseminate (dissemination).

At the initial stage, namely the define stage, the researchers conducted discussions with fellow lecturers. In addition, at this stage, material reviews and literature studies are also carried out. Material review is done by looking at the syllabus for thermodynamics courses, while literature studies use books, journals or other supporting literature.

The next stage is the design stage. The critical thinking skill evaluation instrument was prepared based on Ennis' critical thinking indicators, while the enthusiasm questionnaire instrument was prepared based on needs with the aim of evaluating the entire virtual-based learning process.

In the third stage, namely the develop or development stage. The instrument was validated by a team of experts or lecturer colleagues to determine the theoretical quality of the instrument. After the instrument was repaired according to the advice of the expert team, then the instrument was used as a test in the test class. After the instrument was tested, the instrument was given a response or response by fellow lecturers as instrument users and students. The results of the trial were analyzed for instrument validity for each statement item to determine 
the instrument's validity and reliability analysis to determine the instrument's reliability. Furthermore, the instrument was corrected according to the responses or responses of lecturers and students and issued invalid statements.

The last stage is the dissemination stage. The deployment stage is carried out by distributing the instrument to the thermodynamics class. Furthermore, the results of the development are used as a data collection tool that will be used to: 1) describe critical thinking skills; and 2) to describe the enthusiasm of the students of the Physics Education Study Program at the University of Palangka Raya in the thermodynamics course which is carried out on a virtual basis.

\section{RESULTS AND DISCUSSION}

Assessment of Critical Thinking Skills developed in this study uses an essay test type that is used to measure and assess students' critical thinking skills. The critical thinking skill indicator used in this study is the critical thinking skill indicator from Facione (2015). The assessment of critical thinking skills developed in the form of multiple choice and multiple-choice reasoning descriptions which have answers with definite formulations, so that an objective scoring can be carried out, namely 1 for each correct answer choice and reason and 0 for each wrong answer choice and reason.

Table 1

Validity of Critical Thinking Skills Assessment

\begin{tabular}{|c|c|c|c|c|c|c|}
\hline $\begin{array}{l}\mathbf{N u} \\
\mathbf{m}\end{array}$ & $\begin{array}{l}\text { Critical } \\
\text { Thinking } \\
\text { Criteria }\end{array}$ & $\begin{array}{l}\text { Validity } \\
\text { Score }\end{array}$ & Validity & $\mathbf{R}$ & $\mathbf{a}$ & Reliability \\
\hline 1 & $\begin{array}{l}\text { Interpretati } \\
\text { on }\end{array}$ & 4,00 & Very Valid & $92 \%$ & 0,899 & High $R$. \\
\hline 2 & Analysis & 3,80 & Very Valid & $92 \%$ & 0,774 & High $R$. \\
\hline 3 & Evaluation & 3,40 & Very Valid & $86 \%$ & 0,821 & High R. \\
\hline 4 & Inferention & 3,60 & Very Valid & $88 \%$ & 0,712 & High R. \\
\hline 5 & Eksplanatio & 3,60 & Very Valid & $88 \%$ & 0,838 & High R. \\
\hline 6 & $\begin{array}{l}\mathrm{n} \\
\text { Self } \\
\text { Regulation }\end{array}$ & 3,40 & Very Valid & $86 \%$ & 0,817 & High $R$. \\
\hline
\end{tabular}

The assessment of the validity of the Critical Thinking Skills Assessment for the thermodynamics course is based on content validity, construct validity, and language. The summary of the results of the analysis of the validity of the Critical Thinking Skills Assessment is shown in Table 1. The data in Table 1 shows that the validity score of the Critical Thinking Skills Assessment for the 
thermodynamics course has very valid criteria and the reliability coefficient is included in the reliable criteria. The validator's suggestion to improve the Critical Thinking Skills Assessment is that the instructions are clarified so that students understand better. Table 1 shows that the results of the validator's assessment show that the Critical Thinking Skills Assessment instrument for the thermodynamics course can be used when implementing the thermodynamics course. Each critical thinking criterion has a reliability interval of Cronbach's Alpha $(\alpha)$ which can be used with a slight revision $(0.70<0.90)$.

The value data from the analysis of critical thinking skills in the thermodynamics course is contained in the Appendix. Table 2 shows the details of the value and $\mathrm{N}$-gain data on critical thinking skills for each student. The data in Table 2 shows that the critical thinking skills possessed by students are classified as low criteria.

Table 2

Value and N-gain of Students' Critical Thinking Skills

\begin{tabular}{lllllllll}
\hline Initial & \multicolumn{7}{l}{ Pretest } & \multicolumn{5}{c}{ Posttest } & Coeff. & N- \\
\cline { 2 - 6 } Students & Scor & Mark & Criteri & Scor & Mar & Criteria & N- & gain \\
& $\mathbf{e}$ & & $\mathbf{a}$ & $\mathbf{e}$ & $\mathbf{k}$ & & gain & \\
\hline M1 & 3 & 15 & V. Low & 16 & 80 & High & 0,77 & High \\
M2 & 0 & 0 & V. Low & 15 & 75 & Average & 0,75 & High \\
M3 & 1 & 5 & V. Low & 18 & 90 & V. High & 0,90 & High \\
M4 & 2 & 10 & V. Low & 17 & 85 & High & 0,83 & High \\
M5 & 4 & 20 & V. Low & 17 & 85 & High & 0,81 & High \\
M6 & 1 & 5 & V. Low & 18 & 90 & V. High & 0,90 & High \\
M7 & 0 & 0 & V. Low & 16 & 80 & High & 0,80 & High \\
M8 & 1 & 5 & V. Low & 18 & 90 & V. High & 0,90 & High \\
M9 & 2 & 10 & V. Low & 19 & 95 & V. High & 0,94 & High \\
M10 & 3 & 15 & V. Low & 17 & 85 & High & 0,82 & High \\
M11 & 2 & 10 & V. Low & 20 & 100 & V. High & 1,00 & High \\
M12 & 2 & 10 & V. Low & 20 & 100 & V. High & 1,00 & High \\
M13 & 1 & 5 & V. Low & 18 & 90 & V. High & 0,90 & High \\
M14 & 0 & 0 & V. Low & 15 & 75 & Average & 0,75 & High \\
M15 & 2 & 10 & V. Low & 16 & 80 & High & 0,78 & High \\
M16 & 1 & 5 & V. Low & 16 & 80 & High & 0,79 & High \\
M 17 & 3 & 15 & V. Low & 20 & 100 & V. High & 1,00 & High \\
M18 & 0 & 0 & V. Low & 17 & 85 & High & 0,85 & High \\
M19 & 4 & 20 & V. Low & 20 & 100 & V. High & 1,00 & High \\
M20 & 2 & 10 & V. Low & 16 & 80 & High & 0,78 & High \\
\hline Rata-rata & $\mathbf{1 , 7}$ & $\mathbf{8 , 5}$ & V. Low & $\mathbf{1 7 , 4}$ & $\mathbf{8 7}$ & High & $\mathbf{0 , 8 6}$ & High \\
& & & & $\mathbf{5}$ & & & & \\
\hline
\end{tabular}


Table 3

Analysis of Pretest and Posttest Results

Each Indicator of Students' Critical Thinking Skills

\begin{tabular}{llllllll}
\hline Num & $\begin{array}{l}\text { Critical } \\
\text { Thinking } \\
\text { Criteria }\end{array}$ & Pretest & Category & Postest & Category & $\begin{array}{l}\text { Coeff. } \\
\text { N- } \\
\text { gain }\end{array}$ & $\begin{array}{l}\boldsymbol{N} \text { - } \\
\text { gain }\end{array}$ \\
\hline 1 & Interpretation & 4 & V. Low & 96 & V. High & 0,96 & High \\
2 & Analysis & 4 & V. Low & 90 & V. High & 0,90 & High \\
3 & Evaluation & 3 & V. Low & 88 & High & 0,88 & High \\
4 & Inferention & 2 & V. Low & 83 & High & 0,83 & High \\
5 & Eksplanation & 3 & V. Low & 88 & High & 0,88 & High \\
6 & Self & 2 & V. Low & 77 & Average & 0,77 & High \\
& Regulation & & & & & & \\
\hline
\end{tabular}

Assessment of critical thinking skills (PKBK) is given to students as an initial test (pretest) and a final test (posttest). PKBK is given to evaluate the improvement of students' critical thinking skills after thermodynamics learning is carried out virtually and is arranged according to 6 (six) critical thinking indicators used in this study, namely interpretation, analysis, evaluation, inference, explanation, and self-regulation. PKBK is given to students as research subjects. The critical thinking skill indicator used in this research is the critical thinking skill indicator from Facione (2015). The assessment of critical thinking skills developed is in the form of multiple choice on the grounds that it is in the form of multiple choice. Answers with definite formulas, namely 0 and 1 so that scoring can be done objectively. The PKBK score is converted into 5 (five) criteria, namely: 89\% < x 100\% (Very High); 78\% < x 89\% (High); 64\% < x 78\% (Medium); 55\% < x 64\% (Low); 0\% < x 55\% (Very Low).

The results of the measurement of students' critical thinking skills showed that the average value of critical thinking from 20 students on the pretest was 8.5 with very low criteria $(0 \%<\mathrm{x} 55 \%$ (Very Low). PKBK measurement after the implementation of thermodynamics learning virtual shows the average value of 20 students is 87 with high criteria $(78 \%<\mathrm{x} 89 \%$, Very High), with an N-gain of 0.86 with high criteria, the results show that students' critical thinking skills tend to increase from uncritical to The very drastic increase from very low to high was caused by the following factors: 1) the research subject students were students who had good enthusiasm and willingness to learn, and 2) thermodynamics learning was carried out for 7 meetings by practicing critical thinking skills in each meeting, with Thus, it is assumed that there is a lot of learning time so that it forms good thinking skills students well. 
The results of the implementation show the low posttest which not only illustrates that students have not received learning materials, but also shows that students are not accustomed to expressing critical thinking skills. Critical thinking skills seem to be new to students, even though students have been practicing in several courses with experimental activities in the process. This proves that so far, students have mostly done orders on experimental activity guides, but have not trained critical thinking skills.

\section{Tabel 4}

Student Enthusiasm Questionnaire Answers in Virtual Based Thermodynamics Learning

\begin{tabular}{|c|c|c|}
\hline Num & Declaration & $\begin{array}{l}\text { Percentage } \\
(\%)\end{array}$ \\
\hline \multicolumn{3}{|c|}{ Intention } \\
\hline 1 & Attend more than $80 \%$ of the number of virtual meetings. & 100 \\
\hline 2 & Always show up on time in virtual classes. & 95 \\
\hline \multirow[t]{2}{*}{3} & Complete tasks and upload on time. & 90 \\
\hline & Mean & 95 \\
\hline
\end{tabular}

\section{Purpose}

4 Have studied before the virtual class is implemented the 85 material to be taught/discussed.

$5 \quad$ Prepare questions to be asked of lecturers in virtual 90 classes.

$6 \quad$ Listening and actively participating in the learning 95 process.

Mean 90

\section{Self Potential}

$7 \quad$ Understand the material as a whole after the virtual class $\quad 95$ is implemented.

8 Don't feel burdened by the assigned task. 85

$9 \quad$ Work in groups earnestly. 90

\section{Mean 90}

\section{Positif Thinking}

10 Listen to your friends' opinions seriously and carefully. $\quad 90$

11 Express opinions in a polite and courteous manner $\quad 100$

12 Support the right opinion by presenting scientific reasons 85

Mean 91,7

$\begin{array}{ll}\text { Overall Mean } & 91,7\end{array}$

Student learning success in each indicator of critical thinking skills of interpretation, analysis, evaluation, inference, explanation, and self-regulation shows a moderate to high category with an $\mathrm{N}$-gain of $0.77-0.96$. This is in 
accordance with the results of Emilia's research (2007) showing that the development of student abilities is very rapid, both in writing and critical thinking skills, abilities that play an important role in Indonesian education today. Phan (2010) from his research concluded that the act of critical thinking as another strategy of cognitive self-regulation of learners used in their learning, and critical thinking may be a product of various things that precede, as well as different selfregulation strategies. Critical thinking skills can be developed through the processing of analytical thinking habits and strategic thinking. Theoretical and empirical studies show that critical thinking dispositions can be taught and trained (Woolfolk, 2009) persistently and thoroughly (Fisher, 2009) and continuously (Miri et al., 2007; Qing et al., 2010).

Student enthusiasm is measured by looking at the influencing factors in generating enthusiasm, some of them, (Mujahid, 2012), namely: intentions, goals, self-potential, and positive thinking.

Research on student enthusiasm for learning so far has not been widely used in Classroom Action Research (CAR). The increase in learning outcomes will certainly not just happen, but as a result of an increase in learning process variables, one of which can come from enthusiasm for learning. Lecturers' efforts in practicing critical thinking skills are an effort so that students can build their own knowledge. Students are trained to think and not just read from various sources. The results of Donald's research (2019) found the fact that the calculation of the effect of access to information on student enthusiasm for learning, obtained a linear regression equation, namely $\mathrm{Y}=5.086-0.169 \mathrm{X} 1$. This equation shows that the beta value is negative, which means that the higher the access to information, the lower the enthusiasm for learning, and vice versa.

The results show that students are still enthusiastic in participating in virtual thermodynamics learning, but lecturers must pay attention to the possibility of saturation in subsequent virtual learning. Lecturers must maintain the level of student enthusiasm by paying attention to how to deliver material content virtually by using learning models that increase student activity supported by interesting interactive media. Herdiana, et al (2021) stated that one of the impacts of virtual lectures is that it raises student saturation in attending virtual lectures, this is partly due to internal factors that come from themselves such as unfamiliarity with learning with virtual systems and external factors, such as monotony. lecturers in delivering the material and the absence of friends who can directly be invited to discuss the lecture material.

\section{CONCLUSION}

The results of the research and discussion in this report conclude that this study has completed developing a test instrument for learning outcomes of critical thinking skills and a questionnaire instrument for student enthusiasm in virtualbased thermodynamics learning. Both instruments have been validated by content 
and constructs by experts and tested limited to 20 students of the thermodynamics class of the Physics Education Study Program for the Academic Year 2021/2022, the results obtained are the test instrument for learning critical thinking skills and a questionnaire instrument for student enthusiasm in virtual-based thermodynamics learning that has been developed is included in the valid criteria, with the reliability of Cronbach's Alpha $(\square) 0.712<0.899$ which is included in the high reliability criteria. The implementation of the two instruments in learning resulted in the following conclusions:

1. The critical thinking skills of students of the Physics Education Study Program at the University of Palangka Raya in the thermodynamics course which is carried out on a virtual basis is $87 \%$ with an average $\mathrm{N}$-gain of 0.86 critical thinking skills which is in the high criteria.

2. The enthusiasm of the students of the Physics Education Study Program at the University of Palangka Raya in the thermodynamics course which was carried out on a virtual basis was an average of $91.7 \%$ of students were enthusiastic about the thermodynamics learning which was carried out virtually, which can be seen from the aspect of students' intention to take part in the learning of 95 $\%$, the goal aspect is $90 \%$, the self-potential aspect is $90 \%$ and the positive thinking aspect is $91.7 \%$.

Researchers provide suggestions based on the results of limited trials as follows:

1. Class discussions in virtual learning in thermodynamics courses use a lot of mathematical solutions so that it will be easier to understand when using virtual whiteboard media.

2. If there is a division of the group, then the group members must be truly heterogeneous from various aspects, gender, cognitive ability, academic achievement, individual nature, and individual background.

3. Students must be periodically reminded of each component of critical thinking skills that will be assessed.

4. Lecturers must often and periodically provide questions and feedback in the form of questions that form higher order thinking skills.

\section{REFERENCES}

Andriewongso. (2009). Kekuatan Antusiasme. Tersedia: http://www.andriewongso. com/ [25 Nopember 2020].

Burden, P. R., \& Byrd, D. M. (1994). Methods for effective teaching. New York: Allyn and Bacon Inc.

Costa, A. L., \& Pressceincen, B. Z. (1985). Developing minds: a resource book for teaching thinking. Alexandria: ASCD.

Donald, Samuel S. S. (2019). Determinan antusiasme belajar mahasiswa dalam pembelajaran tari bambu. Jurnal Ecodunamika, 2 (2). 
Ennis, R. H. (2011). The nature of critical thinking: an outline of critical thinking dispositions and abilities. (online) (http://faculty.education. illinois. edu/rhennis/ documents/The Natureof CriticalThinking_51711_000.pdf), diakses tanggal 23 Maret 2015.

Facione, P. A. (2015). Critical thinking: What it is and why it counts. Dipetik November 24, 2016, dari https://www.insightassessment.com/ content/.../ what\&why.pdf

Fell, S.P. (1996). Personal communication (e-mail), associate director of interactive distance learning, Florida State University, FL, 20 September.

Fisher, A. (2001). Critical thinking: an introduction. Cambrigde University Press.

Fisher, A. (2009). Berpikir kritis: Sebuah pengantar. Jakarta: Erlangga.

Garrison. D. R., Anderson, T. \& Archer, W. (2001). Critical thinking and computer conferencing: a model and tool to assess cognitive presence.

Halpern, D. F. (2003). Thought and knowledge. An introduction to critical thinking. New Jersey: Lawrence Erlbaum Associates, Inc.

Hartaji, Damar A. (2012). Motivasi berprestasi pada mahasiswa yang berkuliah dengan jurusan pilihan orangtua. Fakultas Psikologi Universitas Gunadarma.

Hassan, O., \& Mat, R. (2005). A comparative study of two different approaches in teaching thermodynamics. Faculty of Chemical and Natural Resources Engineering, UTM-JB. Disajikan dalam Proceedings of the 2005 Regional Conference on Engineering Education, 12- 13 Desember 2005, Johor, Malaysia.

Hediana, D., Rudiana, R. \& Supriatna. (2021). Kejenuhan mahasiswa dalam mengikuti perkuliahan daring dan strategi penanggulangannya. Edunesia: Jurnal Ilmiah Pendidikan, 2 (1), 293-307.

Hurlock, E. B. (2010). Psikologi perkembangan suatu pendekatan sepanjang rentang kehidupan (Alih Bahasa Istiwidayanti dkk. Edisi Kelima. Jakarta : Erlangga.

Judge, B., Jones, P. \& McCreery, E. (2009). Critical thinking skills for education students. British: Learning Matters.

Kerlinger, F.N., 2006. Asas-asas penelitian behavioral. Edisi 3, Cetakan 7. Gadjah Mada University Press. Yogyakarta.

Kulkarni, V.D. \& Tambade, P.S. (2013). Enhancing the learning of thermodynamics using computer assisted instructions at undergraduate level. Eurasian Journal of Physics and Chemistry Education.5(1):2-10.

Leonard, B. (1996), "Distance learning: work and training overlap", HRMagazine, 4(4), pp. 40-7.

Loverude, M. E., Kautz, C. H., Heron, P. R. L. (2002). Student understanding of the first law of thermodynamics: Relating work to the adiabatic compression of an ideal gas. Am. J. Phys. 70 (2). 
Meltzer, D. E. (2004). Investigation of students' reasoning regarding heat, work, and the first law of thermodynamics in an introductory calculus-based general physics course. Am. J. Phys. 72 (11).

Miri, B., David, B. C., \& Uri, Z. (2007). Purposely teaching for the promotion of higher order thinking skills: A case of critical thinking. Springer Science+Business Media, 37, 353-369.

Moore, B. N., \& Parker, R. (2009). Critical thinking. New York: McGraw-Hill Higher Education.

Moore, K. D. (2005). Effective instructional strategies from theory to practice. Los Angeles: Sage Publications, Inc.

Muhajid, R. 2012. Bangkitkan antusiasme anda. http://reframepositive.com.

Novak, \& Gowin. (1985). Learning how to learn. Cambridge: Cambridge University Press.

Paul, R. W., \& Elder, L. (2002). Critical thinking. Tool for taking charge of your professional and personal life. New York: Prentice Hall An Imprint of Pearson Education Upper Saddle River.

Rainbolt, G. W., \& Dwyer, S. L. (2012). Critical thinking the art of argument. Boston: Wadsworth.

Risamasu, Putu. Victoria. M. (2016). Peran pendekatan keterampilan proses sains dalam pembelajaran IPA. Prosiding seminar Nasional Pendidikan Jayapura. 73-81.

Rudd, R., Baker, M., \& Hoover, T. (2000). Undergraduate agriculture student learning styles and critical thinking abilities: Is there a relationship? Journal of Agricultural Education, 42 (3), 2-12.

Rudinow, J., \& Barry, V. E. (2008). Invitation to critical thinking. Belmont, California: Thomson Wadsworth.

Sudjana, Nana. (2011). Penilaian Hasil Proses Belajar Mengajar. Bandung: PT Remaja Rosdakarya.

Sunaryo. (2011). Analisis kompetensi guru fisika dalam mengimplementasikan KTSP di SMKN di propinsi Lampung. Cakrawala Pendidikan, XXX (3), 505-520.

Tatar, E. \& Oktay, M. (2011). The effectiveness of problem-based learning on teaching the first Law of thermodynamics. Research in Science \& Technological Education, 29(3): 315-332.

Woolfolk, A. (2009). Educational psychology. New York: Pearson. 